\title{
Graft-Free Maxillary Sinus Floor Elevation: A Systematic Review and Meta-Analysis
}

\author{
Deng-Hui Duan, ${ }^{*}$ Jia-Hui Fu, ${ }^{\dagger}$ Wei Qi, ${ }^{\ddagger}$ Yi Du, ${ }^{*}$ Jie Pan, ${ }^{*}$ and Hom-Lay Wang ${ }^{\S}$
}

Background: This systematic review and meta-analysis aims to investigate survival rates of dental implants placed simultaneously with graft-free maxillary sinus floor elevation (GFSFE). Factors influencing amount of vertical bone gain (VBG), protruded implant length (PIL) in sinus at follow-up (PILf), and peri-implant marginal bone loss (MBL) are also evaluated.

Methods: Electronic and manual searches for human clinical studies on simultaneous implant placement and GFSFE using the lateral window or transcrestal approach, published in the English language from January 1976 to March 2016, were conducted. The random-effects model and mixed-effect meta-regression were used to analyze weighted mean values of clinical parameters and evaluate factors that influenced amount of VBG.

Results: Of 740 studies, 22 clinical studies were included in this systematic review. A total of 864 implants were placed simultaneously with GFSFE at edentulous sites having mean residual bone height of $5.7 \pm 1.7 \mathrm{~mm}$. Mean implant survival rate (ISR) was $97.9 \% \pm 0.02 \%$ (range: $93.5 \%$ to $100 \%$ ). Weighted mean MBL was $0.91 \pm 0.11 \mathrm{~mm}$, and it was significantly associated with the postoperative follow-up period $\left(r=0.02 ; R^{2}=43.75 \%\right)$. Weighted mean VBG was $3.8 \pm$ $0.34 \mathrm{~mm}$, and this parameter was affected significantly by surgical approach, implant length, and PIL immediately after surgery (PILi) $\left(r=2.82,0.57,0.80 ; R^{2}=19.10 \%, 39.27 \%\right.$, $83.92 \%$, respectively). Weighted mean PILf was $1.26 \pm$ $0.33 \mathrm{~mm}$ (range: 0.3 to $2.1 \mathrm{~mm}$ ).

Conclusion: Within limitations of the present systematic review, GFSFE with simultaneous implant placement can achieve satisfactory mean ISR of $97.9 \% \pm 0.02 \%$. J Periodontol 2017;88:550-564.

\section{KEY WORDS}

Alveolar bone loss; bone regeneration; bone substitutes; dental implants; sinus floor augmentation; systematic review.

\footnotetext{
* Department of General Dentistry, School and Hospital of Stomatology, Peking University, Beijing, People's Republic of China.

$\dagger$ Discipline of Periodontics, Faculty of Dentistry, National University of Singapore, Singapore, Republic of Singapore.

‡ Department of Endodontics, Jinan Stomatology Hospital, Jinan, Shandong, People's Republic of China.

$\S$ Department of Periodontics and Oral Medicine, School of Dentistry, University of Michigan, Ann Arbor, MI.
}

The edentulous posterior maxilla is frequently a challenging site for dental implant rehabilitation because of inadequate alveolar ridge height and poor bone quality. ${ }^{1,2}$ As such, maxillary sinus augmentation techniques that use lateral window or transcrestal approaches ${ }^{3}$ have been proposed so that a dental implant of regular length (e.g., $10 \mathrm{~mm}$ ) can be placed in a deficient posterior maxillary edentulous site. Numerous systematic reviews have documented that transcrestal or lateral window maxillary sinus augmentation can predictably increase vertical bone height using bone substitutes to fill the elevated space.4-7 Different types of bone substitutes have been used in sinus augmentation to maintain the space created after lifting the Schneiderian membrane off the bone surface. ${ }^{4,8-10}$ Autogenous bone is the gold standard bone graft because of its osteogenicity, osteoinductivity, and osteoconductivity. ${ }^{11}$ However, it is not commonly used in maxillary sinus augmentation because of significant graft resorption over time and donor site morbidity. ${ }^{12-14}$ Other bone substitutes, such as human allograft, bovine xenograft, and synthetic alloplast, have been associated with disease transmission, ${ }^{15,16}$ low vital bone to biomaterial ratio, and low resorption rate. ${ }^{10,17}$ Also, they have been suggested to delay bone regeneration compared with autogenous bone or blood clot alone. ${ }^{12,18,19}$ Some studies even showed that sinuses grafted 
with bone substitutes demonstrated repneumatization $^{20,21}$ and implants placed in grafted sinuses had higher peri-implant marginal bone loss (MBL) compared with native bone. ${ }^{22,23}$

Therefore, some clinicians advocated use of blood clots in place of bone substitutes in sinus floor elevation (SFE). ${ }^{24-26}$ High implant survival rates (ISRs) were reported with graft-free maxillary SFE (GFSFE), in which implants acted as a tent against the elevated Schneiderian membrane. ${ }^{24-28}$ The purpose of this systematic review and meta-analysis is to evaluate effectiveness of GFSFE by assessing amount of vertical bone gain (VBG), protruded implant length (PIL) in sinus immediately after surgery (PILi) and at follow-up (PILf), MBL, and ISR. To the best of the authors' knowledge, this report is the first systematic review and meta-analysis of the value of GFSFE with simultaneous implant placement.

\section{MATERIALS AND METHODS}

\section{Search Strategy}

This systematic review was conducted at the University of Michigan, Ann Arbor, Michigan, from February to May 2016. A search of two electronic databases (PubMed/MEDLINE and Cochrane Central Register of Controlled Trials) for relevant studies published in the English language from January 1976 to March 2016 was performed. Search terms used were: ("sinus" OR "maxillary sinus") AND ("floor elevation" OR "lift" OR "augmentation" OR "elevation" OR "lateral approach" OR "Cosci" OR "crestal approach" OR "transcrestal approach" OR "BAOSFE" OR "OSFE" OR "Summers technique" OR "osteotome-mediated" OR "osteotome") AND (without graft [Title/Abstract] OR no graft [Title/ Abstract] OR graftless [Title/Abstract] OR graft free [Title/Abstract] OR nongraft [Title/Abstract] OR without bone graft [Title/Abstract] OR no bone graft [Title/Abstract] OR nongrafts [Title/ Abstract] OR grafts free [Title/Abstract]). Additionally, manual search of dental- and implantologyrelated journals, including Journal of Dental Research, Clinical Implant Dentistry and Related Research, Clinical Oral Implants Research, International Journal of Oral \& Maxillofacial Implants, Journal of Oral Implantology, and Journal of Oral and Maxillofacial Surgery from January 1976 to March 2016, was also performed to ensure a thorough screening process. Furthermore, a search in the references of included papers was conducted for publications that were not identified electronically. Two examiners (D-HD and $W Q$ ) performed the literature search independently. Any disagreement was resolved either through discussion or after consultation with a third examiner (JP). This systematic review was conducted based on PRISMA guidelines.

\section{Eligibility Criteria}

Articles were included in this systematic review if they fulfilled the following inclusion criteria: 1) human prospective or retrospective clinical studies, cohort studies, or case series; 2) simultaneous implant placement with GFSFE via lateral window or transcrestal approach; 3 ) sample size of $\geq 10$ implants; and 4) reported information on ISR, VBG, PILi, PILf, or MBL. Systematic reviews, animal trials, and those studies using platelet-rich fibrin/plasma as graft material were excluded.

\section{Data Extraction}

Data were extracted from studies that met inclusion criteria. Parameters tabulated were: 1 ) demographics patient sample size, number of augmented sinuses, number of implants placed, and implant system used; 2 ) independent variables - lateral or transcrestal approach, implant diameter, implant length, presence or absence of sinus window bone plate, percentage of membrane perforation, residual bone height (RBH), PILi (computed as the difference between implant length and $\mathrm{RBH}$ ), and longest follow-up period after implant placement; and 3) dependent variables - VBG, PILf, MBL, and ISR.

\section{Statistical Analyses}

Extracted data were analyzed using statistical software.l Study heterogeneity was assessed using DerSimonian and Laird $Q$ test and I-square index. If significant heterogeneity was found, the randomeffects model was chosen to minimize any bias caused by methodologic differences among studies. When heterogeneity values were high, meta-regression was carried out on dependent variables. Forest plots were generated to graphically represent the difference in outcomes for all included studies. $P$ value of 0.05 was used as level of significance, and $R^{2}$ was used as proportion of variance explained by the regression model.

\section{RESULTS}

\section{Literature Search}

A total of 740 studies were found through electronic and manual searches. Of these, 80 studies were selected for full-text evaluation after screening titles and abstracts. After full-text evaluation, 58 studies were excluded (Table 1). ${ }^{6,8,24,25,28-81}$ There were 22 studies that fulfilled the inclusion and exclusion criteria (Table 2) and thus were selected for systematic review and meta-analysis. ${ }^{26,27,82-101}$ Interexaminer reliability was 0.87 . There were three studies ${ }^{19,83,88}$ with two treatment arms, and results from both arms were combined in the analysis. ${ }^{27,87,92,97}$

|| Comprehensive Meta-Analysis (version 2.2), Biostat, Englewood, NJ. 
Table I.

\section{Summary of Excluded Studies}

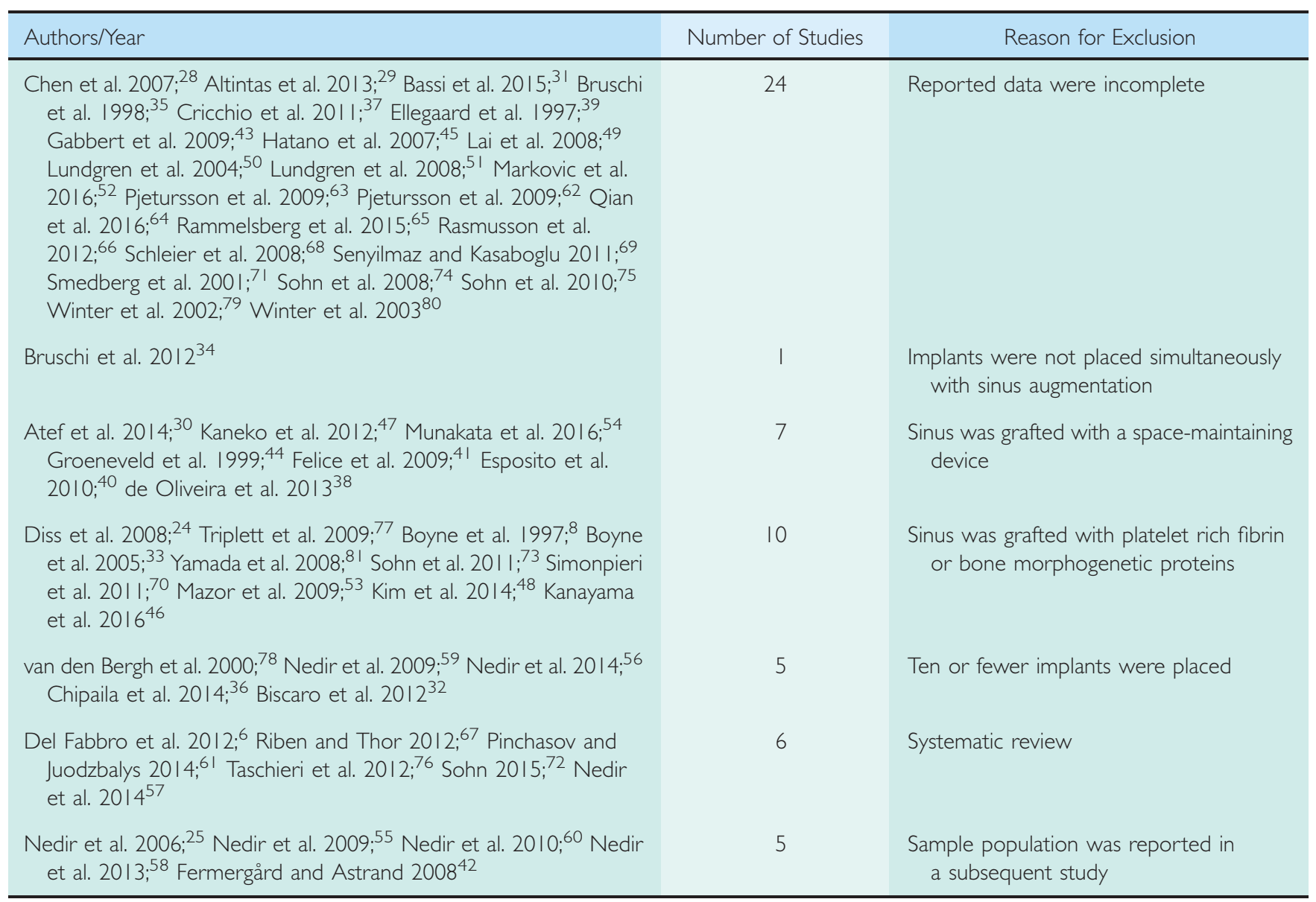

\section{Demographics}

There were 864 implants placed simultaneously with GFSFE at edentulous sites with mean RBH of $5.7 \pm$ $1.7 \mathrm{~mm}$. Mean ISR was reported to be $97.9 \% \pm 0.02 \%$ (range: $93.5 \%$ to $100 \%$ ) with 18 failed implants after mean follow-up duration of $26.6 \pm 24.3$ months (range: 6 months to 10 years). Out of 18 failed implants, 14 reported time of failure, of which $10 \mathrm{im}$ plants $(71.4 \%)$ failed before they were loaded.

\section{Results of Peri-Implant MBL}

Data on MBL were reported in 12 studies. ${ }^{82,84,85,88,90,93,94,96-98,100,101}$ Meta-analysis demonstrated that weighted mean MBL was $0.91 \pm$ $0.11 \mathrm{~mm}$ after mean follow-up period of $41.5 \pm 27.7$ months (range: 9 months to 10 years) with a high degree of heterogeneity $(R=98.92 \% ; P<0.001)$ (Fig. $1 \mathrm{~A})$. To explore influence of postoperative follow-up on MBL, the mixed-effect model was used, and residual $Q$ was reported to be 18.46 with $P=0.03$. Therefore, one study ${ }^{98}$ was excluded for its high heterogeneity despite its long follow-up period of
10 years. Regression analysis showed that MBL was significantly related to postoperative follow-up ( $r=$ $0.02 ; R^{2}=43.75 \%$ ) (Fig. 1B). The surgical approach, implant diameter, implant length, presence or absence of sinus window bone plate, percentage of membrane perforation, RBH, and PILi did not show any significant influence on MBL.

\section{Results of PIL in Sinus at Follow-Ulp (PILf)}

Data on PILf were reported in seven studies. ${ }^{82,84,89,91,97-99}$ Weighted mean PILf was $1.26 \pm$ $0.33 \mathrm{~mm}$ (range: 0.3 to $5.5 \mathrm{~mm}$ ) (Fig. 2) with a high degree of heterogeneity $(R=97.55 \% ; P<0.001)$ among selected studies. However, the surgical approach, implant diameter, implant length, presence or absence of sinus window bone plate, percentage of membrane perforation, RBH, and PILi did not show any significant influence on PILf.

\section{Results of VBG}

Data on VBG were reported in 18 studies. ${ }^{26,27,82-}$ 87,89,91,93,94,96-101 Meta-analysis showed that weighted mean VBG was $3.80 \pm 0.35 \mathrm{~mm}$ (Fig. 3A) 


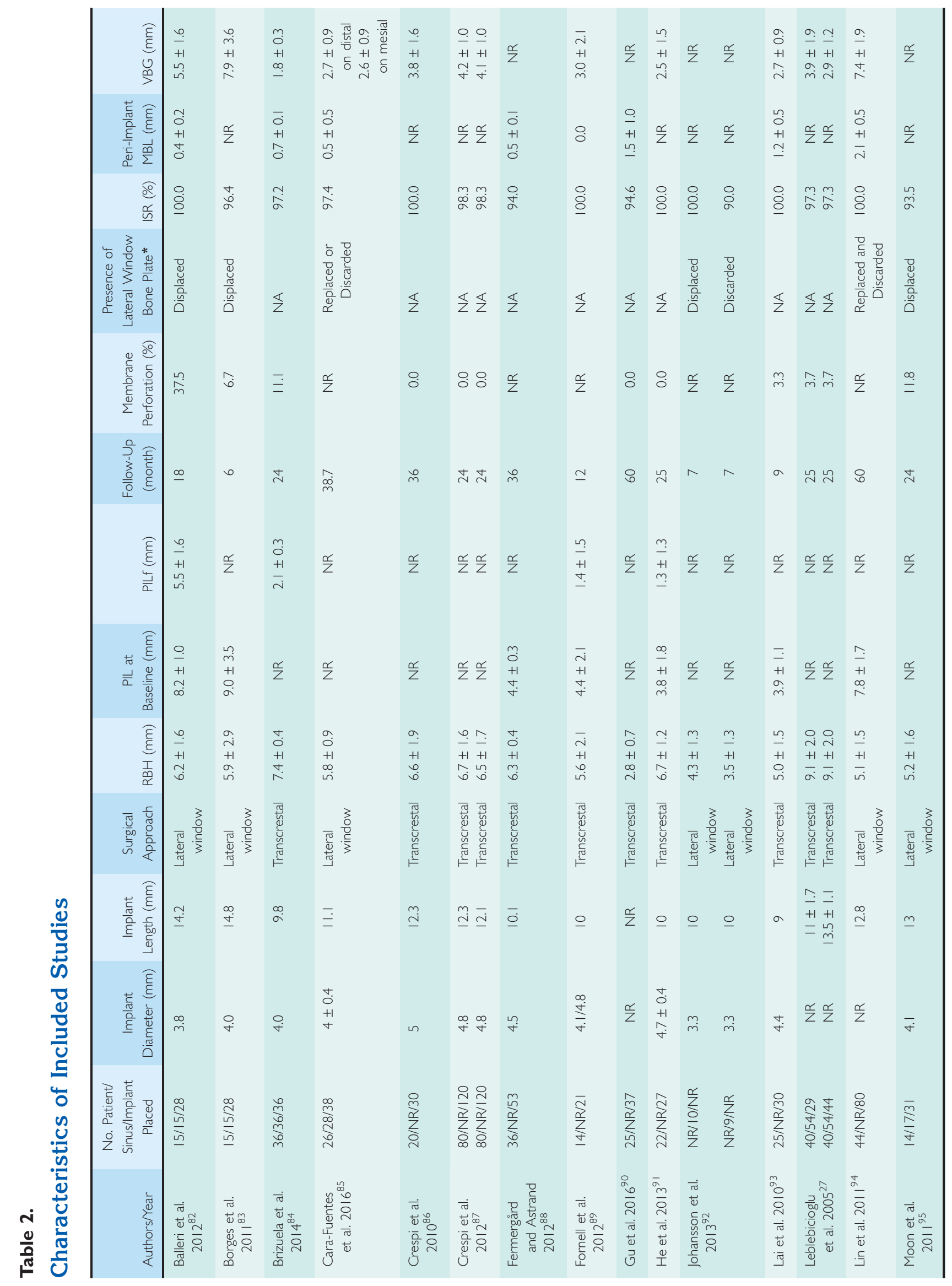




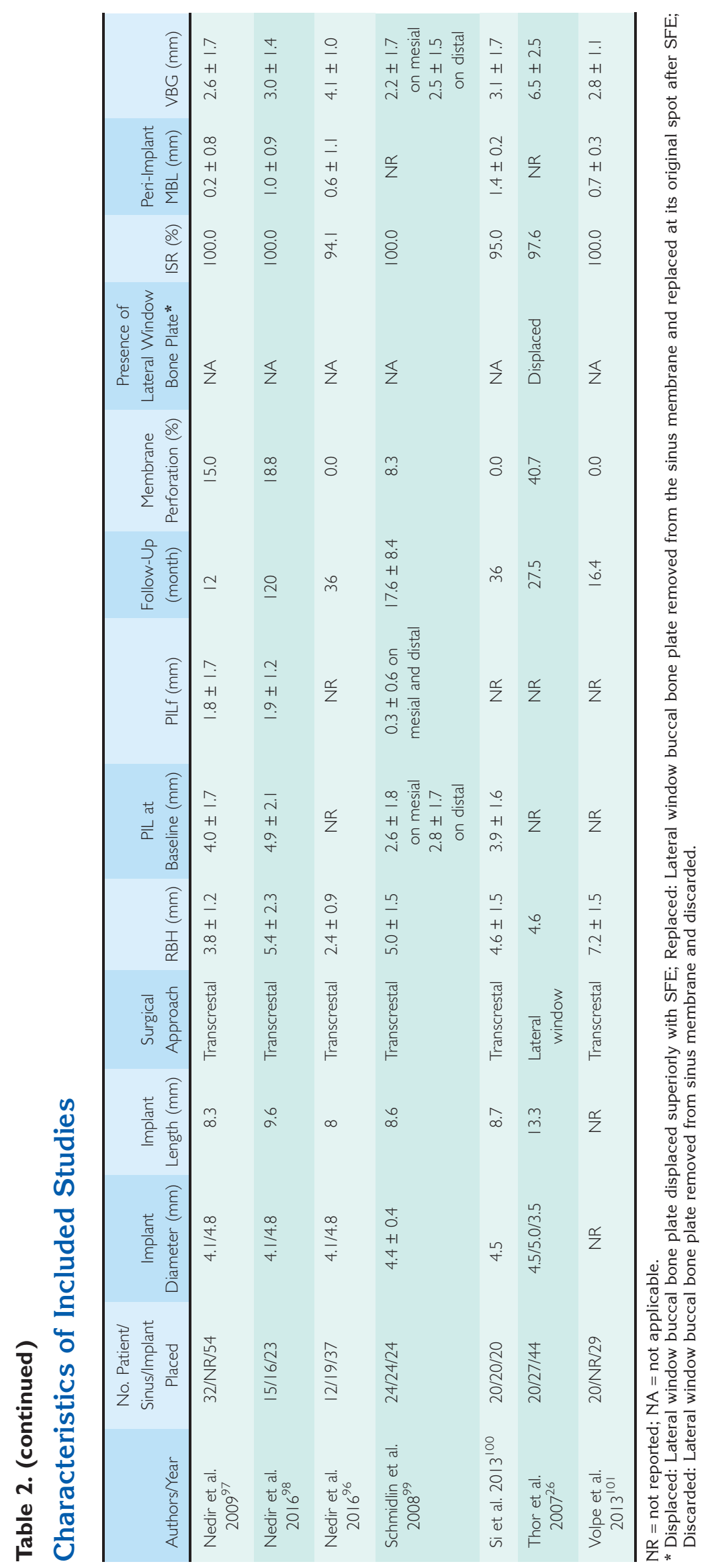




\section{A}

Study name

Balleri et al. $2012^{82}$

Brizuela et al. $2014^{84}$

Fermergard and Astrand et al. $2012^{88}$

Gu et al. $2016^{90}$

Lai et al. $2010^{93}$

Nedir et al. $2009^{97}$

Si et al. $2013^{100}$

Volpe et al. $2013^{101}$
Cara-Fuentes et al. $2016^{85}$

Lin et al. $2011^{94}$

Nedir et al. $2016^{98}$

Nedir et al. $2016^{96}$
Meta-analysis of MBL

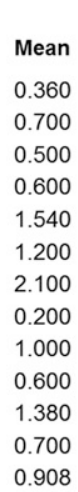

Standard error

0.038

0.017

0.082

0.013

0.169

0.088

0.056

0.109

0.188

0.275

0.053

0.056

0.111

$\begin{array}{rrrrr}\text { Variance } & \begin{array}{c}\text { Lower } \\ \text { limit }\end{array} & \begin{array}{c}\text { Upper } \\ \text { limit }\end{array} & \boldsymbol{Z} \text { value } & \boldsymbol{P} \text { value } \\ 0.001 & 0.286 & 0.434 & 9.525 & <0.001 \\ 0.000 & 0.666 & 0.734 & 40.817 & <0.001 \\ 0.007 & 0.339 & 0.661 & 6.083 & <0.001 \\ 0.000 & 0.575 & 0.625 & 47.140 & <0.001 \\ 0.029 & 1.209 & 1.871 & 9.111 & <0.001 \\ 0.008 & 1.028 & 1.372 & 13.693 & <0.001 \\ 0.003 & 1.990 & 2.210 & 37.566 & <0.001 \\ 0.012 & -0.013 & 0.413 & 1.837 & 0.067 \\ 0.035 & 0.632 & 1.368 & 5.329 & <0.001 \\ 0.076 & 0.061 & 1.139 & 2.182 & 0.023 \\ 0.003 & 1.277 & 1.483 & 26.153 & <0.001 \\ 0.003 & 0.591 & 0.809 & 12.565 & <0.001 \\ 0.012 & 0.690 & 1.126 & 8.153 & <0.001\end{array}$

B

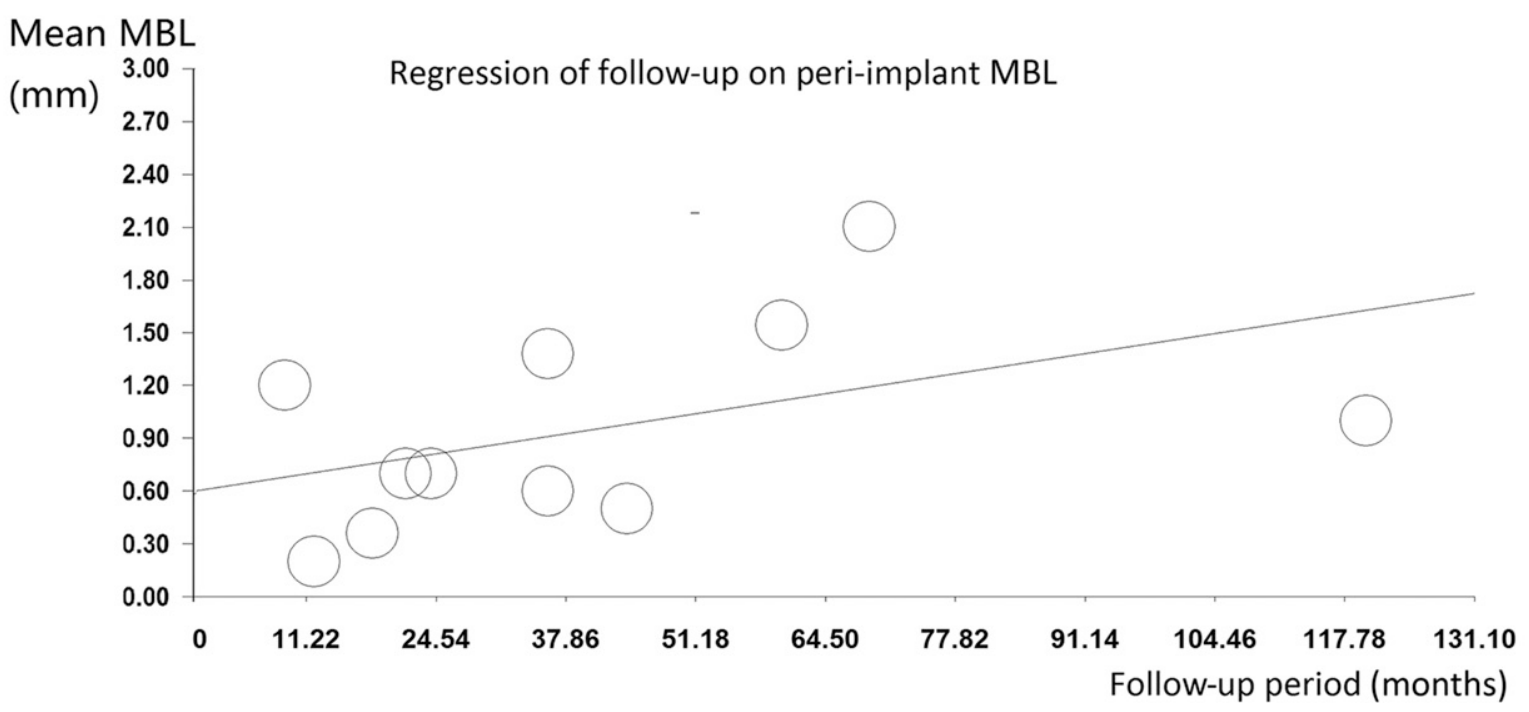

Figure I.

A) Forest plot representing weighted mean MBL of $0.91 \mathrm{~mm}$ ( $95 \%$ confidence interval [Cl] of 0.69 to $1.13 \mathrm{~mm}$ ). B) Meta-regression graph illustrating effect of postoperative follow-up on mean MBL.

Study name

$\begin{array}{ll} & \text { Mean } \\ \text { Schmidlin et al. 2008 } & 0.300 \\ \text { Johansson et al. 2013 } & 0.600 \\ \text { Johansson et al. 2013 } & 0.700 \\ \text { He et al. 2013 } & 1.300 \\ \text { Fornell et al. 2012 } & 1.400 \\ \text { Nedir et al. 2009 } & 1.800 \\ \text { Nedir et al. 2016 } & 1.900 \\ \text { Brizuela et al. 2014 } & 2.100 \\ & 1.257\end{array}$

Meta-analysis of PILf

$\begin{gathered}\text { Standard } \\ \text { error }\end{gathered}$
0.122
0.200
0.126
0.250
0.327
0.231
0.250
0.051
0.331

\begin{tabular}{rrrrr}
\multicolumn{6}{c}{ Meta-analysis of PILf } \\
Variance & $\begin{array}{c}\text { Lower } \\
\text { limit }\end{array}$ & $\begin{array}{c}\text { Upper } \\
\text { limit }\end{array}$ & $\boldsymbol{Z}$ value & $\boldsymbol{P}$ value \\
0.015 & 0.060 & 0.540 & 2.449 & 0.01 \\
0.040 & 0.208 & 0.992 & 3.000 & 0.003 \\
0.016 & 0.452 & 0.948 & 5.534 & $<0.001$ \\
0.063 & 0.810 & 1.790 & 5.196 & $<0.001$ \\
0.107 & 0.758 & 2.042 & 4.277 & $<0.001$ \\
0.054 & 1.347 & 2.253 & 7.781 & $<0.001$ \\
0.063 & 1.410 & 2.390 & 7.593 & $<0.001$ \\
0.003 & 1.999 & 2.201 & 40.817 & $<0.001$ \\
0.110 & 0.608 & 1.907 & 3.794 & $<0.001$
\end{tabular}

Mean and $95 \% \mathrm{Cl}$

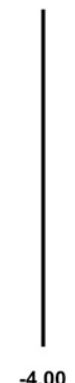

Mean and $95 \% \mathrm{Cl}$

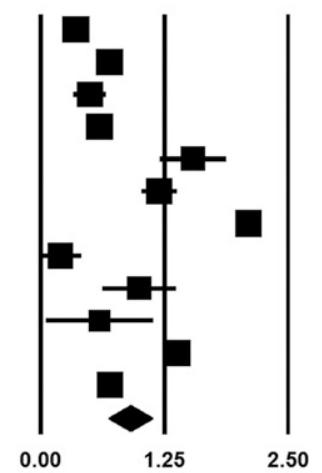


A

Study name

\begin{tabular}{|c|c|c|c|c|c|c|c|}
\hline & Mean & $\begin{array}{l}\text { Standard } \\
\text { error }\end{array}$ & Variance & $\begin{array}{c}\text { Lower } \\
\text { limit }\end{array}$ & $\begin{array}{c}\text { Upper } \\
\text { limit }\end{array}$ & $Z$ value & $P$ value \\
\hline Balleri et al. $2012^{82}$ & 5.500 & 0.302 & 0.091 & 4.907 & 6.093 & 18.190 & $<0.001$ \\
\hline Borges et al. $2011^{83}$ & 7.910 & 0.693 & 0.480 & 6.552 & 9.268 & 11.417 & $<0.001$ \\
\hline Brizuela et al. $2014^{84}$ & 1.800 & 0.051 & 0.003 & 1.699 & 1.901 & 34.986 & $<0.001$ \\
\hline Cara-Fuentes et al. $2016^{85}$ & 2.700 & 0.148 & 0.022 & 2.410 & 2.990 & 18.248 & $<0.001$ \\
\hline Crespi et al. $2010^{86}$ & 3.820 & 0.287 & 0.082 & 3.258 & 4.382 & 13.327 & $<0.001$ \\
\hline Crespi et al. $2012^{87}$ & 4.170 & 0.130 & 0.017 & 3.915 & 4.425 & 32.030 & $<0.001$ \\
\hline Crespi et al. $2012^{87}$ & 4.070 & 0.134 & 0.018 & 3.807 & 4.333 & 30.352 & $<0.001$ \\
\hline Fornell et al. $2012^{89}$ & 3.000 & 0.458 & 0.210 & 2.102 & 3.898 & 6.547 & $<0.001$ \\
\hline He et al. 2013 & 2.500 & 0.289 & 0.083 & 1.934 & 3.066 & 8.660 & $<0.001$ \\
\hline Lai et al. $2010^{93}$ & 2.660 & 0.159 & 0.025 & 2.349 & 2.971 & 16.746 & $<0.001$ \\
\hline Leblebicioglu et al. $2005^{27}$ & 3.900 & 0.353 & 0.124 & 3.208 & 4.592 & 11.054 & $<0.001$ \\
\hline Leblebicioglu et al. $2005^{27}$ & 2.900 & 0.181 & 0.033 & 2.545 & 3.255 & 16.030 & $<0.001$ \\
\hline Lin et al. 2011 & 7.440 & 0.217 & 0.047 & 7.015 & 7.865 & 34.302 & $<0.001$ \\
\hline Nedir et al. $2009^{97}$ & 2.600 & 0.231 & 0.054 & 2.147 & 3.053 & 11.239 & $<0.001$ \\
\hline Nedir et al. 2016 & 3.000 & 0.292 & 0.085 & 2.428 & 3.572 & 10.277 & $<0.001$ \\
\hline Nedir et al. $2016^{6}$ & 4.100 & 0.250 & 0.063 & 3.610 & 4.590 & 16.400 & $<0.001$ \\
\hline Schmidlin et al. 2008 & 2.200 & 0.347 & 0.120 & 1.520 & 2.880 & 6.340 & $<0.001$ \\
\hline Si et al. $2013^{100}$ & 3.070 & 0.385 & 0.149 & 2.315 & 3.825 & 7.965 & $<0.001$ \\
\hline Thor et al. $2007^{60}$ & 6.500 & 0.381 & 0.145 & 5.753 & 7.247 & 17.049 & $<0.001$ \\
\hline \multirow[t]{2}{*}{ Volpe et al. $2013^{101}$} & 2.800 & 0.204 & 0.042 & 2.400 & 3.200 & 13.708 & $<0.001$ \\
\hline & 3.798 & 0.345 & 0.119 & 3.122 & 4.473 & 11.020 & $<0.001$ \\
\hline
\end{tabular}

\section{Mean and $95 \% \mathrm{Cl}$}

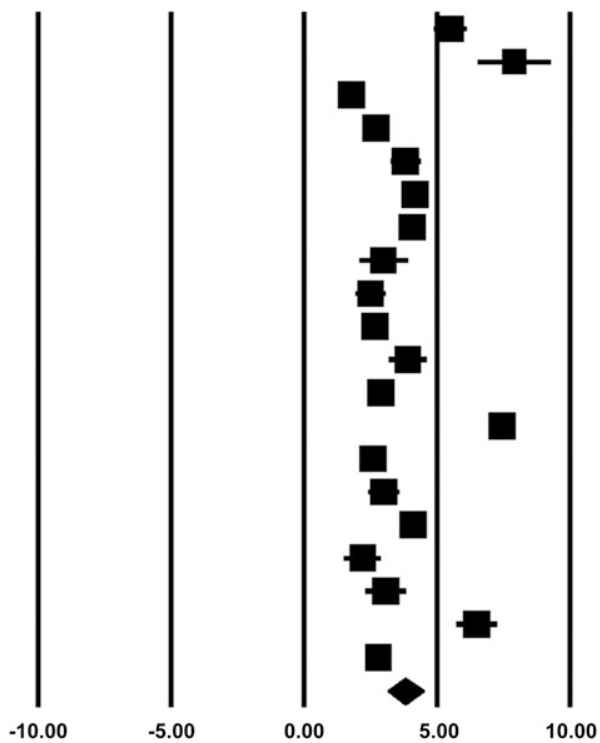

B

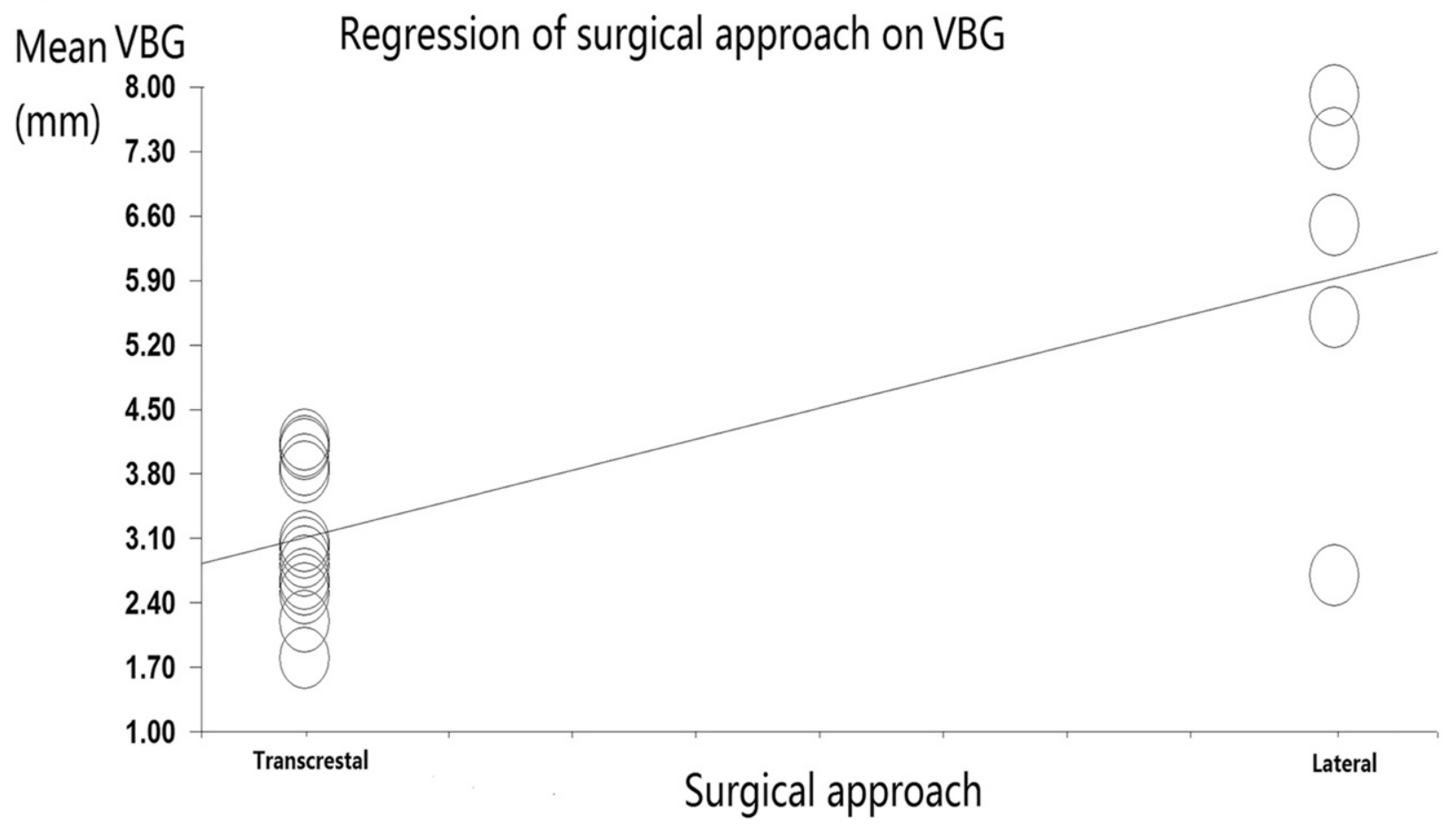

Figure 3.

A) Forest plot representing weighted mean VBG of $3.80 \mathrm{~mm}$ ( $95 \% \mathrm{Cl}$ of 3.12 to $4.47 \mathrm{~mm}$ ). B) Meta-regression graph illustrating effect of surgical approach (transcrestal versus lateral window) on mean VBG. C) Meta-regression graph illustrating effect of implant length on mean VBG. D)

Meta-regression graph illustrating effect of PILi on mean VBG. 
C Mean VBG Regression of implant length on VBG

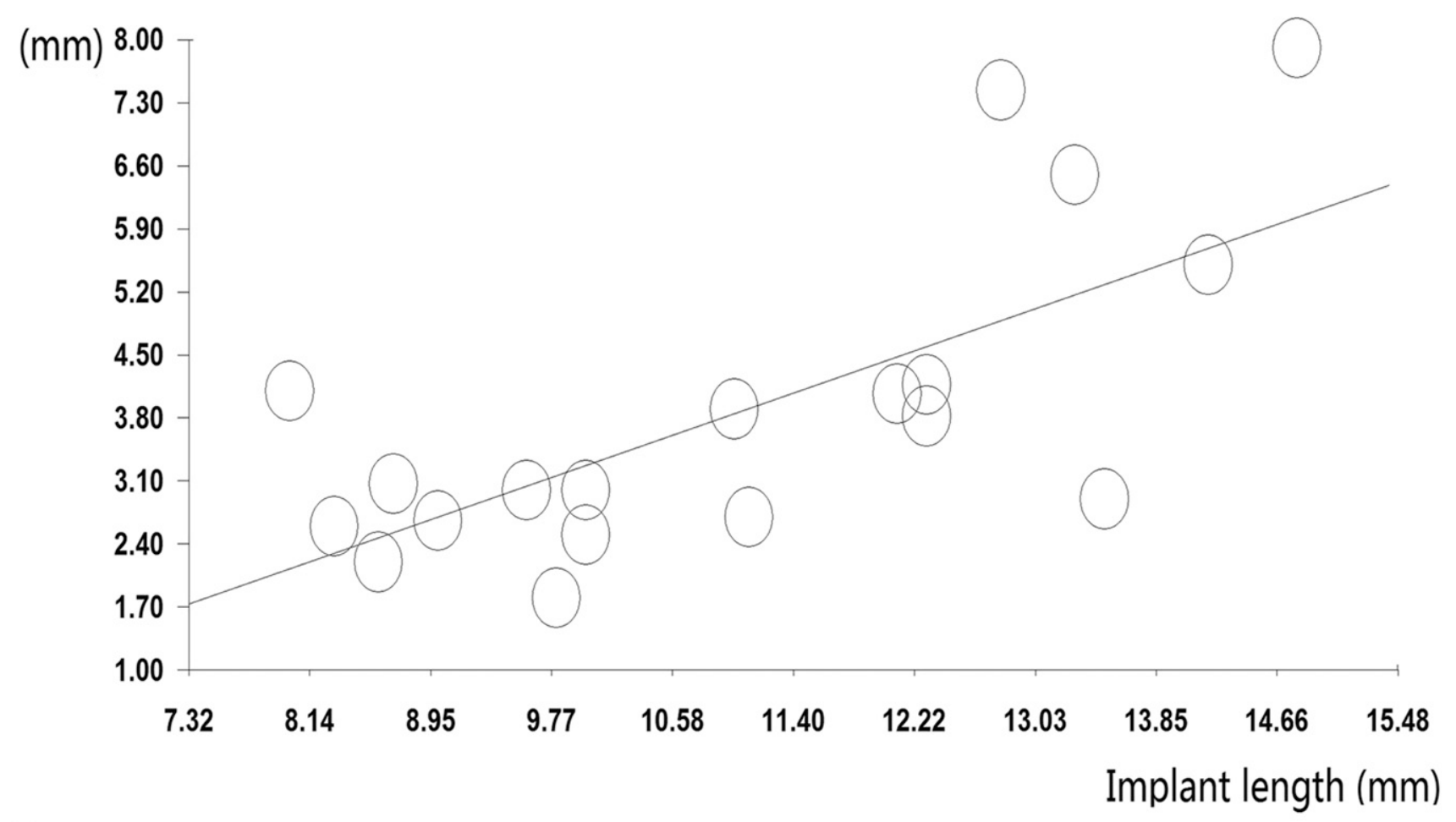

D

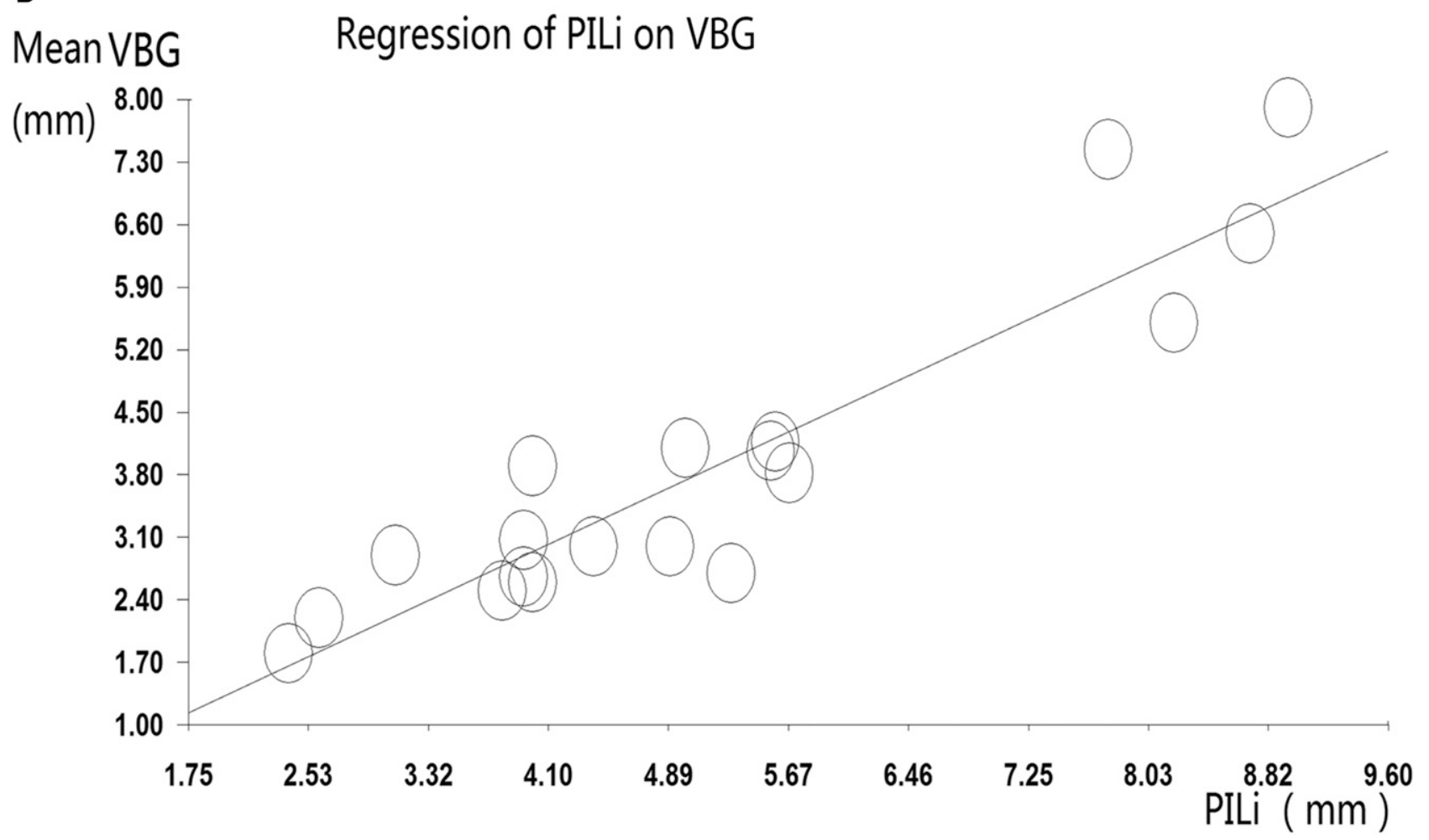


with a high degree of heterogeneity $(R=98.56 \%$; $P<0.001$ ) among selected studies. VBG was found to be greater for the lateral window approach than for the transcrestal approach, and it increased with implant length and protrusion into the sinus cavity. Regression analysis demonstrated a statistically significant effect of the surgical approach, implant length, and PILi on VBG $\left(r=2.82,0.57,0.80 ; R^{2}=\right.$ $19.10 \%, 39.27 \%, 83.92 \%$, respectively) (Figs. 3B through 3D).

\section{DISCUSSION}

Cells, scaffolds, and signaling molecules are integral components in periodontal tissue engineering. ${ }^{102}$ The scaffold holds the space for cells and signaling molecules to act in a well-orchestrated symphony termed regeneration. In implant therapy, bone is the main structure that is regenerated. Numerous techniques, such as tenting titanium mesh, ${ }^{30}$ long titanium screws, ${ }^{47}$ or customized space-maintaining devices, ${ }^{54}$ have been proposed to create and maintain space so that osteogenic cells can proliferate in a protected environment. Therefore, in GFSFE, the implant fixture acts as the tenting device for space creation and maintenance beneath the Schneiderian membrane. This allows formation of a stable blood clot that initiates the wound-healing cascade and promotes bone regeneration. ${ }^{103,104}$

In line with the biologic concept of tissue regeneration, the present study shows that GFSFE appears to perform sufficiently well compared with the conventional approach of adding bone substitutes during augmentation. Meta-analysis highlighted weighted mean VBG of $3.80 \pm 0.35 \mathrm{~mm}$ (range: 1.8 to $7.9 \mathrm{~mm}$ ), which concurred with mean increase in bone height in the transcrestal approach and minimum VBG in the lateral window approach.,104 Therefore, GFSFE was capable of regenerating bone vertically, and amount of VBG was determined by the vertical space generated by protruded implants.

Some studies have suggested a relationship between VBG and types of graft materials ${ }^{105}$ and sinus width/size, ${ }^{106-108}$ but not with PILi ${ }^{109}$ and RBH. ${ }^{110}$ Interestingly, the present study found that VBG was significantly related to PILi $\left(r=0.80 ; R^{2}=83.92 \%\right.$; $P<0.001)$ but not to RBH $(r=-0.19 ; P=0.37)$. This finding can be explained by the PASS principle ${ }^{111}$ of guided bone regeneration, which stands for primary wound closure, angiogenesis, space creation and maintenance, and wound stability. Healing in a graftfree augmented sinus is a temporal sequence of hemostasis, inflammation, proliferation, and maturation/ remodeling. ${ }^{19}$ Space and wound stability are crucial for undifferentiated mesenchymal stem cells or precursor cells within sinus to form bone. ${ }^{112}$ Clinically, mechanical instability in the augmented sinus occurs mainly from air pressure within the sinus associated with respiration. ${ }^{113,114}$ When the Schneiderian membrane is tented by the protruded implant, space created beneath the membrane is relatively stable, thus favoring bone regeneration within the space. ${ }^{103,104,113}$ As such, the amount of VBG is determined by the amount of implant protruding into the sinus.

According to the Wolff law, ${ }^{115,116}$ architecture and volume of regenerated bone within the sinus will change based on the functional load it bears. Maxillary sinuses augmented with bone substitutes, especially autogenous bone, generally undergo continuous bone resorption with a decreasing resorption rate over time. ${ }^{20,21,105,117}$ During the first 6 months of healing, rate of bone resorption was reported to be relatively high, ${ }^{20,21}$ and it gradually tapered down until 6 years after surgery. ${ }^{105,117}$ However, studies reported that GFSFE sites showed continuous but gradually decreasing bone formation. In initial stages of wound healing, VBG approached $2.5 \mathrm{~mm}$ at 6 months after surgery. This value gradually reduced to $\approx 1.5 \mathrm{~mm}$ at 24 months after surgery. ${ }^{86,87}$ Longitudinal studies reported that GFSFE had mean VBG of 2.5, 4.1, 3.2 to 3.8 , and $3.0 \mathrm{~mm}$ at $1-, 3-, 5$-, and 10-year follow-up periods, respectively, ${ }^{25,60,96-98,118}$ thereby indicating a plateauing effect on amount of VBG over time.

Faster bone formation was demonstrated in GFSFE compared with sinuses grafted with xenografts. ${ }^{19}$ In addition, graft-free sinuses had higher bone density than those grafted with allografts ${ }^{29}$ and similar bone-to-implant contact (BIC) as autogenous bone grafted sinuses at 6 months after surgery. ${ }^{92}$ The present systematic review found that weighted mean PILf was $1.26 \pm 0.33 \mathrm{~mm}$, which was greatly reduced from mean PILi of $3.9 \pm 1.1 \mathrm{~mm}$, thus implying that bone regeneration occurred along the implant surface over time. A total of $97.9 \%$ of implants placed simultaneously with GFSFE survived after a mean follow-up period of 28.8 months. This high ISR was perhaps attributed to continuous formation of dense peri-implant bone leading to high BIC and thus functional stable implant restorations. Early implant failure rate of $71.4 \%$ was detected in this analysis, which concurred with implant failure rate of $85.7 \%$ in sinuses augmented with bone substitutes. ${ }^{119}$ Therefore, one can conclude that the early wound-healing phase is critical for osseointegration regardless of whether the sinus is augmented with bone substitutes or blood clot.

Peri-implant MBL is influenced by many biomechanical factors, for example, crown/implant ratio, ${ }^{120}$ excessive cantilever length, ${ }^{121}$ and discrepancy in width of occlusal table and implant fixture diameter. ${ }^{122}$ Finite element analyses have suggested that load distribution and MBL of implants placed in grafted sinuses may be strongly related to 
characteristics of the grafting materials. ${ }^{123-125}$ It was observed that when native bone was stiffer than regenerated bone, functional loading increased concomitant stress at crestal bone level, ${ }^{125}$ resulting in MBL around implants. ${ }^{126}$ Clinical studies corroborated conclusions drawn from finite element analyses, in that MBL around implants in grafted sinuses was significantly greater than that in pristine bone within the first 12 months of functional loading. ${ }^{22,23}$ The present meta-analysis demonstrated that weighted mean MBL around implants placed at sites with GFSFE was $0.91 \pm 0.11 \mathrm{~mm}$ after a follow-up period of 41.9 months. This figure was lower than MBL around implants placed in grafted sinuses ${ }^{23,127,128}$ and pristine maxillary posterior sites. ${ }^{128}$ It could be speculated that the wound-healing cascade in a bonegrafted sinus occurred in an altered manner compared with that in a graft-free sinus, hence the difference in MBL over time. In addition, meta-regression of MBL on duration of postoperative follow-up showed that MBL in GFSFE was time dependent $\left(r=0.02 ; R^{2}=43.75 \%\right)$, with a resorption rate of $0.2 \mathrm{~mm}$ per year. This value was similar to the proposed implant success criteria of $\mathrm{MBL}<0.2 \mathrm{~mm}$ per year from the second year of followup. ${ }^{129,130}$

An area of concern with maxillary SFE is changes to the maxillary sinus cavity and quality of the sinus membrane. Previous animal and human studies found that penetration of dental implants through the Schneiderian membrane and into the sinus cavity had minimal effect on participants. ${ }^{131-133}$ A canine model showed that there were no significant differences between untreated and membrane-lifted sinuses in terms of connective tissue and epithelium thickness, distribution and quantity of globet cells, and cilia orientation. ${ }^{134}$ This implies that SFE did not affect ciliary function and sinus membrane quality and thus could be considered a safe procedure.

There are two limitations associated with this analysis. First, vertical bone dimension was measured on different radiographs; for example, dental panoramic tomograms, standardized or non-standardized periapical radiographs, spiral computed tomograms, and cone-beam computed tomography scans. Second, there was high heterogeneity among studies.

\section{CONCLUSION}

Within the limitations of this systematic review and meta-analysis, GFSFE using the lateral window or transcrestal approach with simultaneous implant placement appears to be a predictable treatment modality.

\section{ACKNOWLEDGMENTS}

This work was partially supported by the University of Michigan Periodontal Graduate Student Research
Fund. The authors report no conflicts of interest related to this study.

\section{REFERENCES}

1. Al-Dajani M. Recent trends in sinus lift surgery and their clinical implications. Clin Implant Dent Relat Res 2016;18:204-212.

2. Sogo M, Ikebe K, Yang TC, Wada M, Maeda Y. Assessment of bone density in the posterior maxilla based on Hounsfield units to enhance the initial stability of implants. Clin Implant Dent Relat Res 2012;14(Suppl. 1):e183-e187.

3. Mohan N, Wolf J, Dym H. Maxillary sinus augmentation. Dent Clin North Am 2015;59:375-388.

4. Jensen T, Schou S, Stavropoulos A, Terheyden H, Holmstrup P. Maxillary sinus floor augmentation with Bio-Oss or Bio-Oss mixed with autogenous bone as graft: A systematic review. Clin Oral Implants Res 2012;23:263-273.

5. Tan WC, Lang NP, Zwahlen M, Pjetursson BE. A systematic review of the success of sinus floor elevation and survival of implants inserted in combination with sinus floor elevation. Part II: Transalveolar technique. J Clin Periodontol 2008;35(Suppl. 8):241-254.

6. Del Fabbro M, Corbella S, Weinstein T, Ceresoli V, Taschieri S. Implant survival rates after osteotomemediated maxillary sinus augmentation: A systematic review. Clin Implant Dent Relat Res 2012;14(Suppl. 1):e159-e168.

7. Pjetursson BE, Tan WC, Zwahlen M, Lang NP. A systematic review of the success of sinus floor elevation and survival of implants inserted in combination with sinus floor elevation. J Clin Periodontol 2008;35 (Suppl. 8):216-240.

8. Boyne PJ, Marx RE, Nevins M, et al. A feasibility study evaluating rhBMP-2/absorbable collagen sponge for maxillary sinus floor augmentation. Int $J$ Periodontics Restorative Dent 1997;17:11-25.

9. Cannizzaro G, Felice P, Leone M, Viola P, Esposito M. Early loading of implants in the atrophic posterior maxilla: Lateral sinus lift with autogenous bone and Bio-Oss versus crestal mini sinus lift and $8-\mathrm{mm}$ hydroxyapatite-coated implants. A randomised controlled clinical trial. Eur J Oral Implantology 2009;2: 25-38.

10. Danesh-Sani SA, Engebretson SP, Janal MN. Histomorphometric results of different grafting materials and effect of healing time on bone maturation after sinus floor augmentation: A systematic review and meta-analysis [published online ahead of print August 18, 2016]. J Periodontal Res. doi:10.1111/ jre.12402.

11. Rosenberg ES, Cutler SA. Guided tissue regeneration and GTAM for periodontal regenerative therapy, ridge augmentation and dental implantology. Alpha Omegan 1992;85:25-28.

12. Klijn RJ, Meijer GJ, Bronkhorst EM, Jansen JA. A meta-analysis of histomorphometric results and graft healing time of various biomaterials compared to autologous bone used as sinus floor augmentation material in humans. Tissue Eng Part B Rev 2010;16: 493-507.

13. Wallace SS, Tarnow DP, Froum SJ, et al. Maxillary sinus elevation by lateral window approach: Evolution of technology and technique. J Evid Based Dent Pract 2012;12(Suppl. 3):161-171. 
14. Klijn RJ, Meijer GJ, Bronkhorst EM, Jansen JA. Sinus floor augmentation surgery using autologous bone grafts from various donor sites: A meta-analysis of the total bone volume. Tissue Eng Part B Rev 2010; 16:295-303.

15. Goldberg VM, Stevenson S. Natural history of autografts and allografts. Clin Orthop Relat Res 1987; (225):7-16.

16. Trotter JF. Transmission of hepatitis C by implantation of a processed bone graft. A case report. J Bone Joint Surg Am 2003;85-A:2215-2217.

17. Corbella S, Taschieri S, Weinstein R, Del Fabbro M. Histomorphometric outcomes after lateral sinus floor elevation procedure: A systematic review of the literature and meta-analysis. Clin Oral Implants Res 2016;27:1106-1122.

18. Handschel J, Simonowska M, Naujoks C, et al. A histomorphometric meta-analysis of sinus elevation with various grafting materials. Head Face Med 2009;5:12.

19. Lambert F, Léonard A, Drion P, Sourice S, Layrolle P, Rompen E. Influence of space-filling materials in subantral bone augmentation: Blood clot vs. autogenous bone chips vs. bovine hydroxyapatite. Clin Oral Implants Res 2011;22:538-545.

20. Kühl S, Payer M, Kirmeier R, Wildburger A, Acham S, Jakse $N$. The influence of particulated autogenous bone on the early volume stability of maxillary sinus grafts with biphasic calcium phosphate: A randomized clinical trial. Clin Implant Dent Relat Res 2015; 17:173-178.

21. Kühl S, Payer M, Kirmeier R, Wildburger A, Wegscheider $\mathrm{W}$, Jakse $\mathrm{N}$. The influence of bone marrow aspirates and concentrates on the early volume stability of maxillary sinus grafts with deproteinized bovine bone mineral - First results of a RCT. Clin Oral Implants Res 2014;25:221-225.

22. Galindo-Moreno P, Leon-Cano A, Ortega-Oller I, et al. Marginal bone loss as success criterion in implant dentistry: Beyond $2 \mathrm{~mm}$. Clin Oral Implants Res 2015;26:e28-e34.

23. Galindo-Moreno P, Fernández-Jiménez A, AvilaOrtiz G, Silvestre FJ, Hernández-Cortés P, Wang HL. Marginal bone loss around implants placed in maxillary native bone or grafted sinuses: A retrospective cohort study. Clin Oral Implants Res 2014; 25:378-384.

24. Diss A, Dohan DM, Mouhyi J, Mahler P. Osteotome sinus floor elevation using Choukroun's platelet-rich fibrin as grafting material: A 1-year prospective pilot study with microthreaded implants. Oral Surg Oral Med Oral Pathol Oral Radiol Endod 2008;105:572-579.

25. Nedir R, Bischof M, Vazquez L, Szmukler-Moncler S, Bernard JP. Osteotome sinus floor elevation without grafting material: A 1-year prospective pilot study with ITI implants. Clin Oral Implants Res 2006;17:679-686.

26. Thor A, Sennerby L, Hirsch JM, Rasmusson L. Bone formation at the maxillary sinus floor following simultaneous elevation of the mucosal lining and implant installation without graft material: An evaluation of 20 patients treated with 44 Astra Tech implants. J Oral Maxillofac Surg 2007;65(7, Suppl. 1):64-72.

27. Leblebicioglu B, Ersanli S, Karabuda C, Tosun T, Gokdeniz H. Radiographic evaluation of dental implants placed using an osteotome technique. J Periodontol 2005;76:385-390.
28. Chen TW, Chang HS, Leung KW, Lai YL, Kao SY. Implant placement immediately after the lateral approach of the trap door window procedure to create a maxillary sinus lift without bone grafting: A 2-year retrospective evaluation of 47 implants in 33 patients. J Oral Maxillofac Surg 2007;65:23242328.

29. Altintas NY, Senel FC, Kayıpmaz S, Taskesen F, Pampu AA. Comparative radiologic analyses of newly formed bone after maxillary sinus augmentation with and without bone grafting. JOral Maxillofac Surg 2013;71:1520-1530.

30. Atef M, Hakam MM, ElFaramawey MI, Abou-ElFetouh A, Ekram M. Nongrafted sinus floor elevation with a space-maintaining titanium mesh: Case-series study on four patients. Clin Implant Dent Relat Res 2014;16:893-903.

31. Bassi AP, Pioto R, Faverani LP, Canestraro D, Fontão FG. Maxillary sinus lift without grafting, and simultaneous implant placement: A prospective clinical study with a 51 -month follow-up. Int J Oral Maxillofac Surg 2015;44:902-907.

32. Biscaro L, Beccatelli A, Landi L. A human histologic report of an implant placed with simultaneous sinus floor elevation without bone graft. Int $J$ Periodontics Restorative Dent 2012;32:e122-e130.

33. Boyne PJ, Lilly LC, Marx RE, et al. De novo bone induction by recombinant human bone morphogenetic protein-2 (rhBMP-2) in maxillary sinus floor augmentation. J Oral Maxillofac Surg 2005;63:1693-1707.

34. Bruschi GB, Crespi R, Capparè P, Gherlone E. Transcrestal sinus floor elevation: A retrospective study of 46 patients up to 16 years. Clin Implant Dent Relat Res 2012;14:759-767.

35. Bruschi GB, Scipioni A, Calesini G, Bruschi E. Localized management of sinus floor with simultaneous implant placement: A clinical report. Int J Oral Maxillofac Implants 1998;13:219-226.

36. Chipaila N, Marini R, Sfasciotti GL, Cielo A, Bonanome L, Monaco A. Graftless sinus augmentation technique with contextual placement of implants: A case report. J Med Case Reports 2014;8:437.

37. Cricchio G, Sennerby L, Lundgren S. Sinus bone formation and implant survival after sinus membrane elevation and implant placement: A 1 - to 6 year follow-up study. Clin Oral Implants Res 2011; 22:1200-1212.

38. de Oliveira GR, Olate S, Cavalieri-Pereira L, et al Maxillary sinus floor augmentation using blood without graft material. Preliminary results in 10 patients. J Oral Maxillofac Surg 2013;71:1670-1675.

39. Ellegaard B, Kølsen-Petersen J, Baelum V. Implant therapy involving maxillary sinus lift in periodontally compromised patients. Clin Oral Implants Res 1997; 8:305-315.

40. Esposito M, Piattelli M, Pistilli R, Pellegrino G, Felice $P$. Sinus lift with guided bone regeneration or anorganic bovine bone: 1-year post-loading results of a pilot randomised clinical trial. Eur J Oral Implantology 2010;3:297-305.

41. Felice P, Scarano A, Pistilli R, et al. A comparison of two techniques to augment maxillary sinuses using the lateral window approach: Rigid synthetic resorbable barriers versus anorganic bovine bone. Fivemonth post-loading clinical and histological results of a pilot randomised controlled clinical trial. Eur $J$ Oral Implantology 2009;2:293-306. 
42. Fermergård R, Astrand P. Osteotome sinus floor elevation and simultaneous placement of implants A 1-year retrospective study with Astra Tech implants. Clin Implant Dent Relat Res 2008;10:62-69.

43. Gabbert O, Koob A, Schmitter M, Rammelsberg P. Implants placed in combination with an internal sinus lift without graft material: An analysis of short-term failure. J Clin Periodontol 2009;36:177-183.

44. Groeneveld EH, van den Bergh JP, Holzmann P, ten Bruggenkate CM, Tuinzing DB, Burger EH. Histomorphometrical analysis of bone formed in human maxillary sinus floor elevations grafted with OP-1 device, demineralized bone matrix or autogenous bone. Comparison with non-grafted sites in a series of case reports. Clin Oral Implants Res 1999;10:499-509.

45. Hatano N, Sennerby L, Lundgren S. Maxillary sinus augmentation using sinus membrane elevation and peripheral venous blood for implant-supported rehabilitation of the atrophic posterior maxilla: Case series. Clin Implant Dent Relat Res 2007;9:150-155.

46. Kanayama T, Horii K, Senga Y, Shibuya Y. Crestal approach to sinus floor elevation for atrophic maxilla using platelet-rich fibrin as the only grafting material: A 1-year prospective study. Implant Dent 2016;25: 32-38.

47. Kaneko T, Masuda I, Horie N, Shimoyama T. New bone formation in nongrafted sinus lifting with space-maintaining management: A novel technique using a titanium bone fixation device. J Oral Maxillofac Surg 2012;70:e217-e224.

48. Kim JM, Sohn DS, Bae MS, Moon JW, Lee JH, Park IS. Flapless transcrestal sinus augmentation using hydrodynamic piezoelectric internal sinus elevation with autologous concentrated growth factors alone. Implant Dent 2014;23:168-174.

49. Lai HC, Zhang ZY, Wang F, Zhuang LF, Liu X. Resonance frequency analysis of stability on ITI implants with osteotome sinus floor elevation technique without grafting: A 5-month prospective study. Clin Oral Implants Res 2008;19:469-475.

50. Lundgren S, Andersson S, Gualini F, Sennerby L. Bone reformation with sinus membrane elevation: A new surgical technique for maxillary sinus floor augmentation. Clin Implant Dent Relat Res 2004;6: $165-173$.

51. Lundgren S, Cricchio G, Palma VC, Salata LA, Sennerby L. Sinus membrane elevation and simultaneous insertion of dental implants: A new surgical technique in maxillary sinus floor augmentation. Periodontol 2000 2008;47:193-205.

52. Markovic A, Misic T, Calvo-Guirado JL, Delgado-Ruíz RA, Janjić B, Abboud M. Two-center prospective, randomized, clinical, and radiographic study comparing osteotome sinus floor elevation with or without bone graft and simultaneous implant placement. Clin Implant Dent Relat Res 2016;18:873-882.

53. Mazor Z, Horowitz RA, Del Corso M, Prasad HS, Rohrer MD, Dohan Ehrenfest DM. Sinus floor augmentation with simultaneous implant placement using Choukroun's platelet-rich fibrin as the sole grafting material: A radiologic and histologic study at 6 months. J Periodontol 2009;80:2056-2064.

54. Munakata M, Tachikawa N, Yamaguchi Y, Sanda M, Kasugai S. The maxillary sinus floor elevation using a poly-L-lactic acid device to create space without bone graft: Case series study of five patients. J Oral Implantol 2016;42:278-284.
55. Nedir R, Bischof M, Vazquez L, Nurdin N, SzmuklerMoncler S, Bernard JP. Osteotome sinus floor elevation technique without grafting material: 3-year results of a prospective pilot study. Clin Oral Implants Res 2009;20:701-707.

56. Nedir R, Nurdin N, El Hage M, Bischof M. Osteotome sinus floor elevation procedure for first molar singlegap implant rehabilitation: A case series. Implant Dent 2014;23:760-767.

57. Nedir R, Nurdin N, Khoury P, et al. Paradigm shift in the management of the atrophic posterior maxilla. Case Rep Dent 2014;2014:486949.

58. Nedir R, Nurdin N, Khoury P, et al. Osteotome sinus floor elevation with and without grafting material in the severely atrophic maxilla. A 1 -year prospective randomized controlled study. Clin Oral Implants Res 2013;24:1257-1264.

59. Nedir R, Nurdin N, Szmukler-Moncler S, Bischof M. Osteotome sinus floor elevation technique without grafting material and immediate implant placement in atrophic posterior maxilla: Report of 2 cases. $J$ Oral Maxillofac Surg 2009;67:1098-1103.

60. Nedir R, Nurdin N, Vazquez L, Szmukler-Moncler S, Bischof M, Bernard JP. Osteotome sinus floor elevation technique without grafting: A 5-year prospective study. J Clin Periodontol 2010;37:1023-1028.

61. Pinchasov G, Juodzbalys G. Graft-free sinus augmentation procedure: A literature review. J Oral Maxillofac Res 2014;5:e1.

62. Pjetursson BE, Ignjatovic D, Matuliene G, Brägger U, Schmidlin K, Lang NP. Transalveolar maxillary sinus floor elevation using osteotomes with or without grafting material. Part II: Radiographic tissue remodeling. Clin Oral Implants Res 2009;20:677-683.

63. Pjetursson BE, Rast C, Brägger U, Schmidlin K, Zwahlen M, Lang NP. Maxillary sinus floor elevation using the (transalveolar) osteotome technique with or without grafting material. Part I: Implant survival and patients' perception. Clin Oral Implants Res 2009;20:667-676.

64. Qian SJ, Gu YX, Mo JJ, Qiao SC, Zhuang LF, Lai HC. Resonance frequency analysis of implants placed with osteotome sinus floor elevation in posterior maxillae. Clin Oral Implants Res 2016;27:113-119.

65. Rammelsberg P, Mahabadi J, Eiffler C, Koob A, Kappel S, Gabbert O. Radiographic monitoring of changes in bone height after implant placement in combination with an internal sinus lift without graft material. Clin Implant Dent Relat Res 2015;17 (Suppl. 1):e267-e274.

66. Rasmusson L, Thor A, Sennerby L. Stability evaluation of implants integrated in grafted and nongrafted maxillary bone: A clinical study from implant placement to abutment connection. Clin Implant Dent Relat Res 2012;14:61-66.

67. Riben C, Thor A. The maxillary sinus membrane elevation procedure: Augmentation of bone around dental implants without grafts - A review of a surgical technique. Int J Dent 2012;2012:105483.

68. Schleier P, Bierfreund G, Schultze-Mosgau S, Moldenhauer F, Küpper H, Freilich M. Simultaneous dental implant placement and endoscope-guided internal sinus floor elevation: 2-year post-loading outcomes. Clin Oral Implants Res 2008;19:11631170.

69. Senyilmaz DP, Kasaboglu O. Osteotome sinus floor elevation without bone grafting and simultaneous 
implant placement in the atrophic maxilla: A pilot study. Indian J Dent Res 2011;22:786-789.

70. Simonpieri A, Choukroun J, Del Corso M, Sammartino G, Dohan Ehrenfest DM. Simultaneous sinus-lift and implantation using microthreaded implants and leukocyte- and platelet-rich fibrin as sole grafting material: A six-year experience. Implant Dent 2011; 20:2-12.

71. Smedberg JI, Johansson P, Ekenbäck D, Wannfors D. Implants and sinus-inlay graft in a 1-stage procedure in severely atrophied maxillae: Prosthodontic aspects in a 3-year follow-up study. Int $J$ Oral Maxillofac Implants 2001;16:668-674.

72. Sohn DS. Paradigm shift regarding sinus augmentation. J Korean Assoc Oral Maxillofac Surg 2015;41: 57-58.

73. Sohn DS, Heo JU, Kwak DH, et al. Bone regeneration in the maxillary sinus using an autologous fibrin-rich block with concentrated growth factors alone. Implant Dent 2011;20:389-395.

74. Sohn DS, Lee JS, Ahn MR, Shin HI. New bone formation in the maxillary sinus without bone grafts. Implant Dent 2008; 17:321-331.

75. Sohn DS, Moon JW, Moon KN, Cho SC, Kang PS. New bone formation in the maxillary sinus using only absorbable gelatin sponge. J Oral Maxillofac Surg 2010;68:1327-1333.

76. Taschieri S, Corbella S, Saita M, Tsesis I, Del Fabbro $M$. Osteotome-mediated sinus lift without grafting material: A review of literature and a technique proposal. Int J Dent 2012;2012:849093.

77. Triplett RG, Nevins M, Marx RE, et al. Pivotal, randomized, parallel evaluation of recombinant human bone morphogenetic protein-2/absorbable collagen sponge and autogenous bone graft for maxillary sinus floor augmentation. JOral Maxillofac Surg 2009;67:1947-1960.

78. van den Bergh JP, ten Bruggenkate CM, Groeneveld $\mathrm{HH}$, Burger EH, Tuinzing DB. Recombinant human bone morphogenetic protein-7 in maxillary sinus floor elevation surgery in 3 patients compared to autogenous bone grafts. A clinical pilot study. J Clin Periodontol 2000;27:627-636.

79. Winter AA, Pollack AS, Odrich RB. Placement of implants in the severely atrophic posterior maxilla using localized management of the sinus floor: A preliminary study. Int $\mathrm{J}$ Oral Maxillofac Implants 2002;17:687-695.

80. Winter AA, Pollack AS, Odrich RB. Sinus/alveolar crest tenting (SACT): A new technique for implant placement in atrophic maxillary ridges without bone grafts or membranes. Int $J$ Periodontics Restorative Dent 2003;23:557-565.

81. Yamada Y, Nakamura S, Ito K, et al. Injectable tissueengineered bone using autogenous bone marrowderived stromal cells for maxillary sinus augmentation: Clinical application report from a 2-6-year follow-up. Tissue Eng Part A 2008;14:1699-1707.

82. Balleri P, Veltri M, Nuti N, Ferrari M. Implant placement in combination with sinus membrane elevation without biomaterials: A 1-year study on 15 patients. Clin Implant Dent Relat Res 2012;14: 682-689 (erratum 2013;15:470).

83. Borges FL, Dias RO, Piattelli A, et al. Simultaneous sinus membrane elevation and dental implant placement without bone graft: A 6-month follow-up study. $J$ Periodontol 2011;82:403-412.
84. Brizuela A, Martín N, Fernández-Gonzalez FJ, Larrazábal C, Anta A. Osteotome sinus floor elevation without grafting material: Results of a 2-year prospective study. J Clin Exp Dent 2014;6:e479-e484.

85. Cara-Fuentes M, Machuca-Ariza J, Ruiz-Martos A, Ramos-Robles MC, Martínez-Lara I. Long-term outcome of dental implants after maxillary augmentation with and without bone grafting. Med Oral Patol Oral Cir Bucal 2016;21:e229-e235.

86. Crespi R, Capparè P, Gherlone E. Osteotome sinus floor elevation and simultaneous implant placement in grafted biomaterial sockets: 3 years of follow-up. $J$ Periodontol 2010;81:344-349.

87. Crespi R, Capparè P, Gherlone E. Sinus floor elevation by osteotome: Hand mallet versus electric mallet. A prospective clinical study. Int $J$ Oral Maxillofac Implants 2012;27:1144-1150.

88. Fermergård R, Astrand P. Osteotome sinus floor elevation without bone grafts - A 3-year retrospective study with Astra Tech implants. Clin Implant Dent Relat Res 2012;14:198-205.

89. Fornell J, Johansson LA, Bolin A, Isaksson S, Sennerby L. Flapless, CBCT-guided osteotome sinus floor elevation with simultaneous implant installation. I: Radiographic examination and surgical technique. A prospective 1-year follow-up. Clin Oral Implants Res 2012;23:28-34.

90. Gu YX, Shi JY, Zhuang LF, Qian SJ, Mo JJ, Lai HC. Transalveolar sinus floor elevation using osteotomes without grafting in severely atrophic maxilla: A 5year prospective study. Clin Oral Implants Res 2016; 27:120-125.

91. He L, Chang X, Liu Y. Sinus floor elevation using osteotome technique without grafting materials: A 2year retrospective study. Clin Oral Implants Res 2013;24(Suppl. A100):63-67.

92. Johansson LA, Isaksson S, Bryington M, Dahlin C. Evaluation of bone regeneration after three different lateral sinus elevation procedures using microcomputed tomography of retrieved experimental implants and surrounding bone: A clinical, prospective, and randomized study. Int $J$ Oral Maxillofac Implants 2013;28:579-586.

93. Lai HC, Zhuang LF, Lv XF, Zhang ZY, Zhang YX, Zhang ZY. Osteotome sinus floor elevation with or without grafting: A preliminary clinical trial. Clin Oral Implants Res 2010;21:520-526.

94. Lin IC, Gonzalez AM, Chang HJ, Kao SY, Chen TW. A 5 -year follow-up of 80 implants in 44 patients placed immediately after the lateral trap-door window procedure to accomplish maxillary sinus elevation without bone grafting. Int J Oral Maxillofac Implants 2011;26:1079-1086.

95. Moon JW, Sohn DS, Heo JU, Shin HI, Jung JK. New bone formation in the maxillary sinus using peripheral venous blood alone. J Oral Maxillofac Surg 2011;69:2357-2367.

96. Nedir R, Nurdin N, Khoury P, Bischof M. Short implants placed with or without grafting in atrophic sinuses: The 3-year results of a prospective randomized controlled study. Clin Implant Dent Relat Res 2016;18:10-18.

97. Nedir R, Nurdin N, Szmukler-Moncler S, Bischof M. Placement of tapered implants using an osteotome sinus floor elevation technique without bone grafting: 1-year results. Int $J$ Oral Maxillofac Implants 2009;24:727-733. 
98. Nedir R, Nurdin N, Vazquez L, Abi Najm S, Bischof M. Osteotome sinus floor elevation without grafting: A 10-year prospective study. Clin Implant Dent Relat Res 2016;18:609-617.

99. Schmidlin PR, Müller J, Bindl A, Imfeld H. Sinus floor elevation using an osteotome technique without grafting materials or membranes. Int $J$ Periodontics Restorative Dent 2008;28:401-409.

100. Si MS, Zhuang LF, Gu YX, Mo JJ, Qiao SC, Lai HC. Osteotome sinus floor elevation with or without grafting: A 3-year randomized controlled clinical trial. J Clin Periodontol 2013;40:396-403.

101. Volpe S, Lanza M, Verrocchi D, Sennerby L. Clinical outcomes of an osteotome technique and simultaneous placement of Neoss implants in the posterior maxilla. Clin Implant Dent Relat Res 2013;15:2228.

102. Lynch SE, Wisner-Lynch L, Nevins M, Nevins ML. A new era in periodontal and periimplant regeneration: Use of growth-factor enhanced matrices incorporating rhPDGF. Compend Contin Educ Dent 2006;27:672-678, quiz 679-680.

103. Xu H, Shimizu Y, Ooya K. Histomorphometric study of the stability of newly formed bone after elevation of the floor of the maxillary sinus. $\mathrm{Br} \mathrm{J}$ Oral Maxillofac Surg 2005;43:493-499.

104. Sohn DS, Moon JW, Lee WH, et al. Comparison of new bone formation in the maxillary sinus with and without bone grafts: Immunochemical rabbit study. Int J Oral Maxillofac Implants 2011;26:1033-1042.

105. Shanbhag S, Shanbhag V, Stavropoulos A. Volume changes of maxillary sinus augmentations over time: A systematic review. Int J Oral Maxillofac Implants 2014;29:881-892.

106. Soardi CM, Spinato S, Zaffe D, Wang HL. Atrophic maxillary floor augmentation by mineralized human bone allograft in sinuses of different size: An histologic and histomorphometric analysis. Clin Oral Implants Res 2011;22:560-566.

107. Spinato S, Bernardello F, Galindo-Moreno P, Zaffe D. Maxillary sinus augmentation by crestal access: A retrospective study on cavity size and outcome correlation. Clin Oral Implants Res 2015;26:13751382.

108. Zheng X, Teng M, Zhou F, Ye J, Li G, Mo A. Influence of maxillary sinus width on transcrestal sinus augmentation outcomes: Radiographic evaluation based on cone beam CT. Clin Implant Dent Relat Res 2016;18:292-300.

109. Sul SH, Choi BH, Li J, Jeong SM, Xuan F. Effects of sinus membrane elevation on bone formation around implants placed in the maxillary sinus cavity: An experimental study. Oral Surg Oral Med Oral Pathol Oral Radiol Endod 2008;105:684-687.

110. Avila-Ortiz G, Neiva R, Galindo-Moreno P, Rudek I, Benavides E, Wang HL. Analysis of the influence of residual alveolar bone height on sinus augmentation outcomes. Clin Oral Implants Res 2012;23: 1082-1088.

111. Wang HL, Boyapati L. "PASS" principles for predictable bone regeneration. Implant Dent 2006;15: 8-17.

112. Frank V, Kaufmann S, Wright R, et al. Frequent mechanical stress suppresses proliferation of mesenchymal stem cells from human bone marrow without loss of multipotency. Sci Rep 2016;6: 24264.
113. Asai S, Shimizu Y, Ooya K. Maxillary sinus augmentation model in rabbits: Effect of occluded nasal ostium on new bone formation. Clin Oral Implants Res 2002;13:405-409.

114. Chanavaz M. Maxillary sinus: Anatomy, physiology, surgery, and bone grafting related to implantology Eleven years of surgical experience (1979-1990). J Oral Implantol 1990;16:199-209.

115. Frost HM. From Wolff's law to the mechanostat: A new "face" of physiology. J Orthop Sci 1998;3: 282-286.

116. Frost HMA. A 2003 update of bone physiology and Wolff's Law for clinicians. Angle Orthod 2004;74:3-15.

117. Sbordone C, Toti P, Guidetti F, Califano L, Bufo P, Sbordone L. Volume changes of autogenous bone after sinus lifting and grafting procedures: A 6-year computerized tomographic follow-up. J Craniomaxillofac Surg 2013;41:235-241.

118. Nedir R, Nurdin N, Abi Najm S, El Hage M, Bischof $M$. Short implants placed with or without grafting into atrophic sinuses: The 5-year results of a prospective randomized controlled study [published online ahead of print June 13, 2016]. Clin Oral Implants Res 2016.

119. Barone A, Orlando B, Tonelli P, Covani U. Survival rate for implants placed in the posterior maxilla with and without sinus augmentation: A comparative cohort study. J Periodontol 2011;82:219-226.

120. Garaicoa-Pazmiño C, Suárez-López del Amo F, Monje A, et al. Influence of crown/implant ratio on marginal bone loss: A systematic review. J Periodontol 2014;85:1214-1221.

121. Anitua E, Piñas L, Orive G. Retrospective study of short and extra-short implants placed in posterior regions: Influence of crown-to-implant ratio on marginal bone loss. Clin Implant Dent Relat Res 2015;17:102-110.

122. Ozgur GO, Kazancioglu HO, Demirtas N, Deger S, Ak G. Risk factors associated with implant marginal bone loss: A retrospective 6-year follow-up study. Implant Dent 2016;25:122-127.

123. Fanuscu MI, Vu HV, Poncelet B. Implant biomechanics in grafted sinus: A finite element analysis. $J$ Oral Implantol 2004;30:59-68.

124. Inglam S, Suebnukarn S, Tharanon W, Apatananon T, Sitthiseripratip K. Influence of graft quality and marginal bone loss on implants placed in maxillary grafted sinus: A finite element study. Med Biol Eng Comput 2010;48:681-689.

125. Huang HL, Fuh LJ, Ko CC, Hsu JT, Chen CC. Biomechanical effects of a maxillary implant in the augmented sinus: A three-dimensional finite element analysis. Int J Oral Maxillofac Implants 2009; 24:455-462.

126. Kitamura E, Stegaroiu R, Nomura S, Miyakawa O. Biomechanical aspects of marginal bone resorption around osseointegrated implants: Considerations based on a three-dimensional finite element analysis. Clin Oral Implants Res 2004;15:401412.

127. Galindo-Moreno P, Fernández-Jiménez A, O’Valle $F$, et al. Marginal bone loss in implants placed in grafted maxillary sinus. Clin Implant Dent Relat Res 2015;17:373-383.

128. Johansson B, Wannfors K, Ekenbäck J, Smedberg JI, Hirsch J. Implants and sinus-inlay bone grafts in a 1-stage procedure on severely atrophied 
maxillae: Surgical aspects of a 3-year follow-up study. Int J Oral Maxillofac Implants 1999;14:811-818.

129. Albrektsson T, Zarb G, Worthington P, Eriksson AR. The long-term efficacy of currently used dental implants: A review and proposed criteria of success. Int J Oral Maxillofac Implants 1986;1:11-25.

130. Peñarrocha-Diago MA, Flichy-Fernández AJ, Alonso-González R, Peñarrocha-Oltra D, BalaguerMartínez J, Peñarrocha-Diago M. Influence of implant neck design and implant-abutment connection type on peri-implant health. Radiological study. Clin Oral Implants Res 2013;24:1192-1200.

131. Tabrizi R, Amid R, Taha Özkan B, Khorshidi H, Langner NJ. Effects of exposing dental implant to the maxillary sinus cavity. J Craniofac Surg 2012;23:767-769.

132. Zhong W, Chen B, Liang X, Ma G. Experimental study on penetration of dental implants into the maxillary sinus in different depths. J Appl Oral Sci 2013;21:560-566.
133. Elhamruni LM, Marzook HA, Ahmed WM, AbdulRahman M. Experimental study on penetration of dental implants into the maxillary sinus at different depths. Oral Maxillofac Surg 2016;20:281-287.

134. Sul SH, Choi BH, Li J, Jeong SM, Xuan F. Histologic changes in the maxillary sinus membrane after sinus membrane elevation and the simultaneous insertion of dental implants without the use of grafting materials. Oral Surg Oral Med Oral Pathol Oral Radiol Endod 2008;105:e1-e5.

Correspondence: Prof. Hom-Lay Wang, Department of Periodontics and Oral Medicine, School of Dentistry, University of Michigan, 1011 North University Ave., Ann Arbor, MI 48109-1078. Fax: 734/936-0374; e-mail: homlay@umich.edu.

Submitted October 15, 2016; accepted for publication December 25, 2016. 